\title{
Inhibition of U-87 MG glioblastoma by AN-152 (AEZS-108), a targeted cytotoxic analog of luteinizing hormone-releasing hormone
}

\author{
Miklos Jaszberenyi ${ }^{1,2,3}$, Andrew V. Schally ${ }^{1,2,3,4,5}$, Norman L. Block ${ }^{1,2,3,4}$, Mehrdad \\ Nadji $^{3}$, Irving Vidaurre ${ }^{1,2}$, Luca Szalontay ${ }^{1,2}$, Ferenc G. Rick ${ }^{1,2}$ \\ ${ }^{1}$ Veterans Affairs Medical Center, Miami, FL \\ 2 South Florida VA Foundation for Research and Education, Miami, FL 33125 \\ ${ }^{3}$ Department of Pathology, University of Miami, Miller School of Medicine, Miami, FL \\ ${ }^{4}$ Division of Hematology/Oncology, University of Miami, Miller School of Medicine, Miami, FL \\ ${ }^{5}$ Division of Endocrinology, Department of Medicine, University of Miami, Miller School of Medicine, Miami, FL \\ Correspondence to: Andrew V. Schally, email: andrew.schally@va.gov
}

Ferenc G. Rick, email: ferencrick@gmail.com

Keywords: glioblastoma multiforme, U-87 MG, cytotoxic, LHRHor GnRH receptors, AN-152, AEZS-108, nude mice, targeted therapy Received: March 5, $2013 \quad$ Accepted: March 6, 2013

Published: March 7, 2013

This is an open-access article distributed under the terms of the Creative Commons Attribution License, which permits unrestricted use, distribution, and reproduction in any medium, provided the original author and source are credited.

\section{ABSTRACT:}

Glioblastoma multiforme is the most frequent tumor of the central nervous system in adults and has a dismal clinical outcome, which necessitates the development of new therapeutic approaches. We investigated in vivo the action of the targeted cytotoxic analog of luteinizing hormone releasing hormone, AN-152 (AEZS-108) in nude mice ( $\mathrm{Ncr}$ nu/nu strain) bearing xenotransplanted U-87 MG glioblastoma tumors. We evaluated in vitro the expression of LHRH receptors, proliferation, apoptosis and the release of oncogenic and tumor suppressor cytokines. Clinical and U-87 MG samples of glioblastoma tumors expressed LHRH receptors. Treatment of nude mice with AN-152, once a week at an intravenous dose of $413 \mathrm{nmol} / 20 \mathrm{~g}$, for six weeks resulted in $76 \%$ reduction in tumor growth. AN-152 nearly completely abolished tumor progression and elicited remarkable apoptosis in vitro. Genomic (RT-PCR) and proteomic (ELISA, Western blot) studies revealed that AN-152 activated apoptosis, as reflected by the changes in p53 and its regulators and substrates, inhibited cell growth, and elicited changes in intermediary filament pattern. AN-152 similarly reestablished contact regulation as demonstrated by expression of adhesion molecules and inhibited vascularization, as reflected by the transcription of angiogenic factors. Our findings suggest that targeted cytotoxic analog AN-152 (AEZS-108) should be considered for a treatment of glioblastomas.

\section{INTRODUCTION}

Malignant tumors are frequently difficult to treat using conventional chemotherapy treatment. However, targeted cytotoxic peptide analogs could overcome this problem. $[1,2]$ Since various neuropeptides play a pivotal role in carcinogenesis, their appropriate receptors can be targeted with cytotoxic peptide complexes.[1,3] Targeting increases efficacy, while reducing toxic side effects[1] on innocent bystander tissues, because, through receptor internalization, the cytotoxic compounds selectively cross the cell membrane of the target cells.[1, 2, 4, 5] Our group has synthesized analogs of luteinizing hormone releasing hormone (LHRH), somatostatin, and bombesin linked to doxorubicin (DOX) or 2-pyrrolinodoxorubicin.[1-3, 6-8] LHRH[9] and its receptor (LHRH-R) are not confined to the hypothalamic-pituitary axis.[10] In the periphery, the LHRH system coordinates gonadal functions and serves as a growth factor of benign conditions [11-13] and various malignancies.[10, 14] In the central nervous system (CNS), hypothalamic and extra-hypothalamic cell populations can be detected [15, 
16], where dense immunostaining for LHRH and LHRH-R can be demonstrated.[15-17] Beside endocrine functions, these cells are involved in the regulation of the olfactory system, feeding, reproductive behavior and circadian rhythms [15, 16, 18]. The LHRH-positive subventricular zone, a frequent starting locus of primary glioblastoma multiforme (GBM) [19], often shows hypertrophy and hyperplasia, in the absence of steroid feed-back, in postmenopausal and andropausal subjects [17]. Since this age-group has the highest prevalence of GBM [20], and GBM tumors frequently show high expression of LHRH-R [21, 22], these findings suggest a regulatory role of the LHRH system in the evolution of brain cancer. The modulation of the LHRH system is used for the treatment of several cancers. LHRH agonists are the mainstay in the therapy of prostate cancer and act through the downregulation of LHRH-R.[23] Moreover, our previous studies showed that the LHRH antagonist, cetrorelix[24], and the cytotoxic analog, AN-152[25] can be successfully used for the treatment of cancers of the reproductive system[25] and of other organs.[1, 2, 26-28]

In the present study, we first demonstrated LHRH-R expression on clinical samples of GBM and U-87 MG cells by immunohistochemistry (IHC) and Western blot. In vitro, U-87 MG cells were exposed to AN-152 and viable cells were determined by proliferation assay. Subsequently, the effectiveness of the cytotoxic analog, AN-152 was evaluated, in vivo, on the growth of U-87 MG tumors xenotransplanted into nude mice. To evaluate its mechanism of action, the most frequently involved "cancer pathway" genes were screened with real-time PCR arrays. Also, apoptotic processes and drug resistance were detected by specific kits. The ability of a chemotherapeutic drug to pass through the cell membrane and to accumulate within the cellular compartments of the neoplastic tissue is one of its most important pharmacodynamic features. Intracellular accumulation was tested by competition with a fluorescent test compound on multidrug resistance (MDR) pumps, by which cells get rid of toxic foreign molecules. Proteomic verification of functional and genomic changes was performed by Western blots and ELISAs.

\section{RESULTS}

\section{LHRH-R expression}

The dense expression of LHRH-R on clinical samples of GBM was shown by the positive reaction in the form of brown granules (Fig. 1).

\section{Animal studies}

Groups of nude mice bearing U-87 MG tumors were treated once a week for 6 weeks with AN-152, DOX,
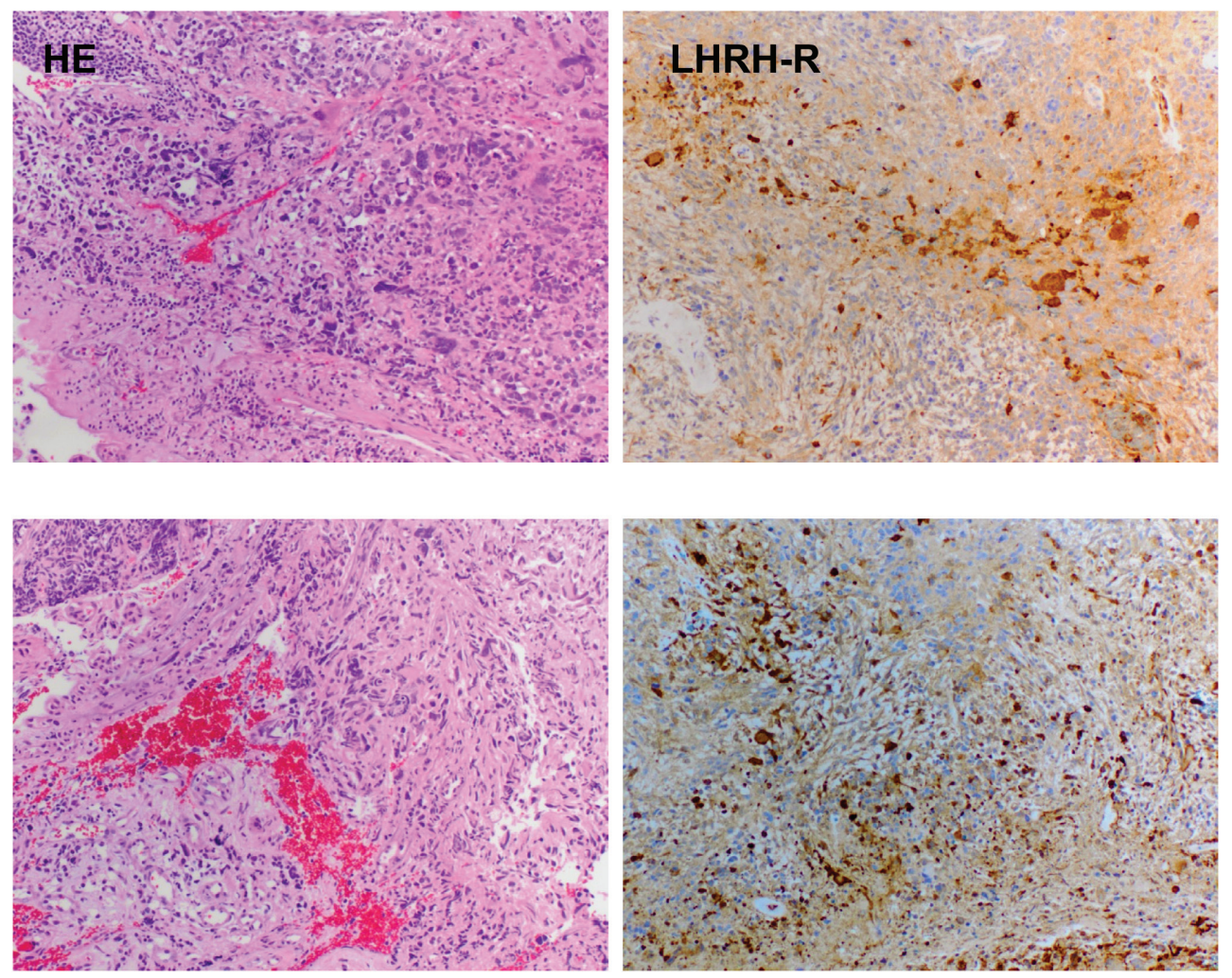

Figure 1: Expression of receptors for LHRH in two representative human GBM specimens. The samples were stained by hematoxylin-eosin (panel HE) and IHC (with affinity-purified goat polyclonal antibody, Santa Cruz, panel LHRH-R). Magnification is 50×. 
D-Trp6-LHRH mimicking the carrier molecule, or with the combination of DOX and D-Trp6-LHRH. Treatment with AN-152 produced the greatest inhibition (Fig. 2) and repeated measure ANOVA revealed significant effects (Within-Subject F5,62=17.87, p $<0.01$, Between-Subject $\mathrm{F} 4,66=78.6, \mathrm{p}<0.01)$. With pair-wise comparison only the effect of AN-152 was significant compared to the control (Tukey's HSD test: $p<0.01$ vs. control), which suggests that targeting greatly increased the effectiveness of therapy. A similar tendency could be observed in the length of tumor doubling times (given in days; control: 10.02, DOX: 13.75, D-Trp6-LHRH: 13.32, DOX + D-Trp6-LHRH: 10.32, AN-152: 19.88), although this effect did not prove to be statistically significant.

\section{Proliferation, Apoptosis and MDR assays}

Single exposure to AN-152 brought about an almost $70 \%$ inhibition of tumor cell growth (Fig. 3/A, F4,284=374.49, $\mathrm{p}<0.01$; Tukey's post hoc $\mathrm{p}<0.01$ vs. control in both cases). Treatment with DOX or the unconjugated combination also led to growth suppression but to a lesser extent. The group treated with AN-152 was statistically different from the DOX treated one (Tukey's post hoc: $\mathrm{p}<0.01$ vs. DOX).

Both DOX and AN-152 elicited a significant increase in apoptosis $(\mathrm{F} 4,91=110.61, \mathrm{p}<0.01$, Tukey's post hoc test: $p<0.01$ vs. control). Again, AN-152 was the most effective (with almost $250 \%$ increase) and its effect was statistically more significant than that of DOX (Tukey's post hoc: $\mathrm{p}<0.01$ vs. DOX; Fig. 3/B). These assays, measuring viable cell count and cell death, confirmed our in vivo findings. Further, in both cases, the targeted cytotoxic compound was significantly more effective than DOX itself.
In the MDR assay, only AN-152 caused a greater increase in calcein retention than the Cyclosporin-A positive control ( $F 4,117=46.8, \mathrm{p}<0.01$; Tukey's post hoc test: $\mathrm{p}<0.01$ vs. positive control). Treatment with AN-152 proved to be significant even compared to DOX (Tukey's post hoc test: $\mathrm{p}<0.01$ vs. DOX; Fig. 3/C). Presumably receptor mediated internalization leads to significantly higher intracellular concentrations of DOX, which, in turn leads to overload of MDR transporters that try to eliminate toxic, foreign compounds from the cell. The increased competition on the MDR transporters, eventually results in increased calcein retention.

\section{PCR experiments}

PCR array studies revealed a significant antitumor effect of AN-152 on the marker regulators of cell proliferation and cell death (nuclear factor $\kappa \mathrm{B}(\mathrm{NF}$ $\kappa \mathrm{B})$, platelet derived growth factor (PDGF), metastasis associated 1 family, member 2 (MTA2)), contact and humoral control (integrins, tumor necrosis factor receptor $10 \beta$ (TNF-R10 $\beta$ )), invasion (MMP-9, urokinase plasminogen activator (UPA)) and metastasis formation (melanoma cell adhesion molecule (MCAM), MTA2). Compared to the parallel treatments AN-152 generally elicited more profound changes in gene expression and its activity on invasion, angiogenesis and metastasis markers (uPA, MMP-9, MCAM, MTA2) was especially significant (Table 1).

\section{Western blot and ELISA experiments}

Western blot studies (Fig. 4) verified the expression of LHRH-R expression in U-87 MG xenograft samples.

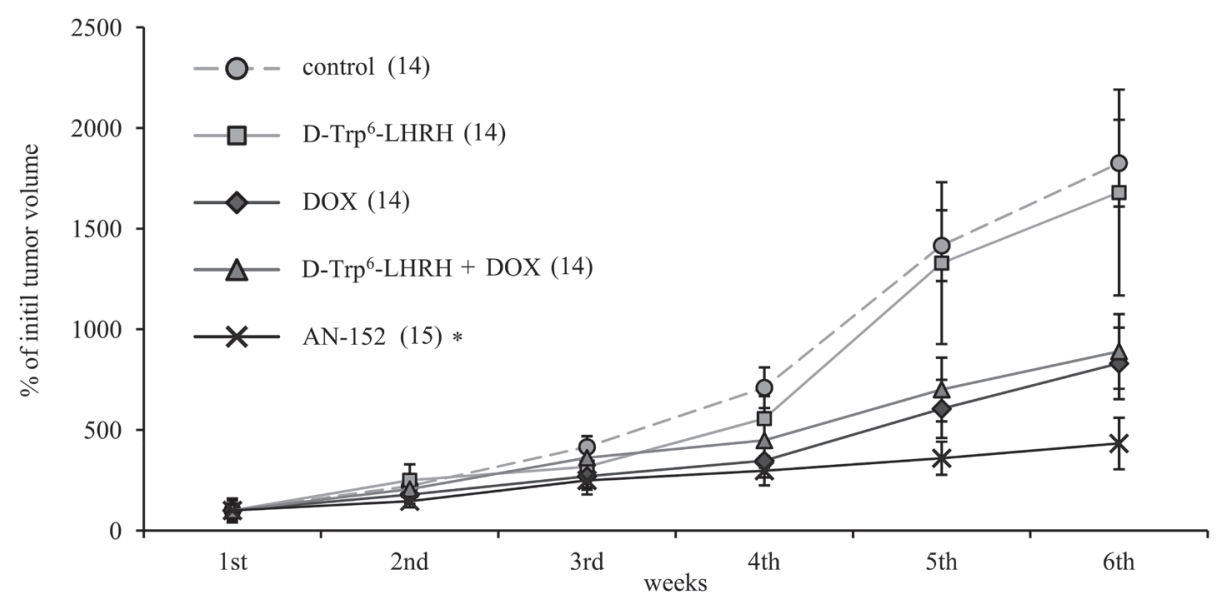

Figure 2: The effect of the cytotoxic LHRH analog, AN-152 (AEZS-108), on the growth of xenotransplanted U-87 MG, human glioblastoma tumors. The pooled standard errors of the groups: control: 313.9; D-Trp 6 -LHRH: 645.3; doxorubicin (DOX): 267.8, D-Trp 6 -LHRH + DOX: 308.9; AN-152: 172.1. Numbers in brackets are the number of successfully grafted tumors. Numbers at the end of each line represents the tumor doubling times. ${ }^{*}=p<0.05$ vs. control for the repeated measure evaluation of tumor growth progression curves. 
Importantly, AN-152 treatment did not induce any downregulation of LHRH-R. These experiments also verified the remarkable up-regulation of the tumor suppressor and pro-apoptotic p53 by the cytotoxic analog (IDVs: control: 4102.7 \pm 1096.7 , AN-152: 14895.0 \pm 1153.4$)$. Further, AN152 reestablished contact inhibition through up-regulation of E-cadherin (IDVs: control: 6636.6 \pm 2042.0 , AN-152: $21925.7 \pm 163.7)$ and down-regulation of $\beta$-catenin (IDVs: control: $16392.5 \pm 2155.3$, AN-152: $1349.6 \pm 757.2)$. One of the most important results of the Western blot studies was that the cytotoxic analog inhibited the expression of the primordial, neuroectodermal stem cell marker, nestin (IDVs: control: $3149.1 \pm 157.1$, AN-152: 739.5 \pm 143.5 ) and stimulated the synthesis of the maturation antigen, GFAP (IDVs: control: 12007.7 \pm 2209.8 , AN-152: $16179.6 \pm 758.845)$.

The level of several oncogenic cytokines and tumor suppressor molecules was modified by the AN-152 treatment as shown by ELISA (Fig. 5). First, these studies, using homogenized cell culture samples, confirmed the increase of p53 and the decrease of $\beta$-catenin observed in the Western blot experiments. The statistical analyses showed significant changes in both cases $(\mathrm{F} 4,14=7.2$, $\mathrm{p}<0.01$, Tukey's post hoc test: $\mathrm{p}<0.01$ vs. control $(\mathrm{n}=4)$ for p53 and F4,23=32.48, p<0.01, Tukey's post hoc test: $\mathrm{p}<0.01$ vs. control $(\mathrm{n}=5)$ for $\beta$-catenin). In addition, $F G F \beta$, one of the decisive markers of glial growth, and VEGF, the most important factor of tumor vascularization and nutrition, were significantly down-regulated by AN-152 treatment $(\mathrm{F} 4,19=7.8, \mathrm{p}<0.01$, Tukey's post hoc test: $\mathrm{p}<0.01$ vs. control $(\mathrm{n}=5)$ for $F G F \beta ; F 4,11=4.8, \mathrm{p}<0.05$, Tukey's post hoc test: $\mathrm{p}<0.05$ vs. control $(\mathrm{n}=3)$ for VEGF). The expression of the maturation marker, GFAP, was reduced by the treatment with DOX (F4,26=14.67, $\mathrm{p}<0.01$, Tukey's post hoc test: $\mathrm{p}<0.01$ vs. control $(\mathrm{n}=6)$ ).
This suggests dedifferentiation or the survival of an immature aggressive proliferation prone phenotype. AN152 treatment caused a much lesser reduction $(\mathrm{p}<0.01 \mathrm{vs}$. DOX), which suggests that the cytotoxic analog, most importantly, may inhibit the survival of resistant stem celllike clones.

\section{DISCUSSION}

Our IHC and Western blot analyses clearly demonstrated that LHRH-R is expressed on human GBM cells, suggesting a role of intrinsic LHRH secretion in the autocrine/paracrine control of GBM cells (Fig. 1, 4). The treatment with ligands of LHRH-R did not down-regulate the LHRH receptors, which augurs well for continuing long term therapy with AN-152. D-Trp6LHRH representing the carrier molecule exerted only a weak effect on in vivo and in vitro tumor growth (Fig. 2 Fig. 3/A) and the expression of adhesion molecules and growth factors (Table 1, Fig. 4-5). However, in the case of some oncoproteins such as MAPK1, the MAPK activator, V-raf-1 murine leukemia viral oncogene homolog 1 (Raf-1), phosphoinositide-3-kinase (PI3K) and the differentiation marker, GFAP, the changes reached the level elicited by the AN-152 treatment.

AN-152 elicited profound inhibition of tumor growth both in vivo (Fig 2) and in vitro (Fig. 3/A), and the effect of the cytotoxic analog exceeded that of DOX (Fig. 2-5). This intensified antitumor potential appears to be related to the "homing property" of the cytotoxic analog[4], which can lead to an increased competition on the MDR transporter proteins reflected by the increased calcein retention in the MDR studies. However, according to the PCR experiments, D-Trp6-LHRH mimicking the carrier molecule, may also act as an inhibitor of the MAPK

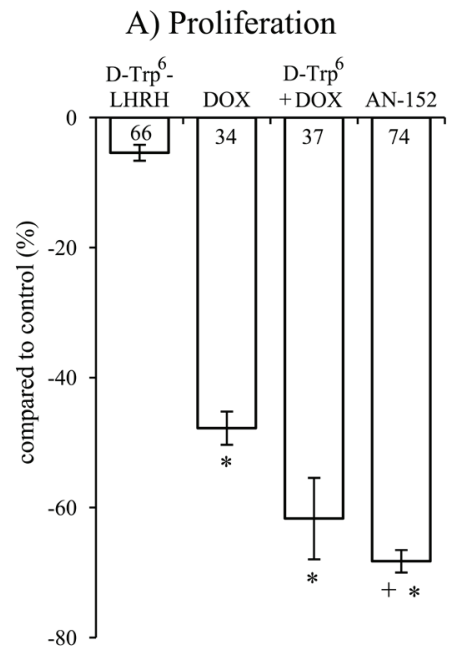

B) Apoptosis

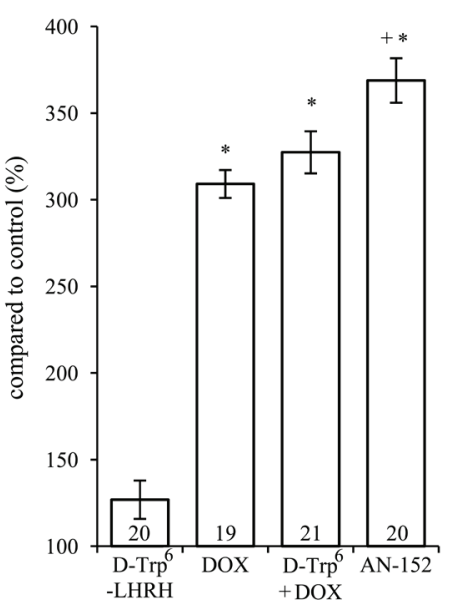

C) Calcein retention

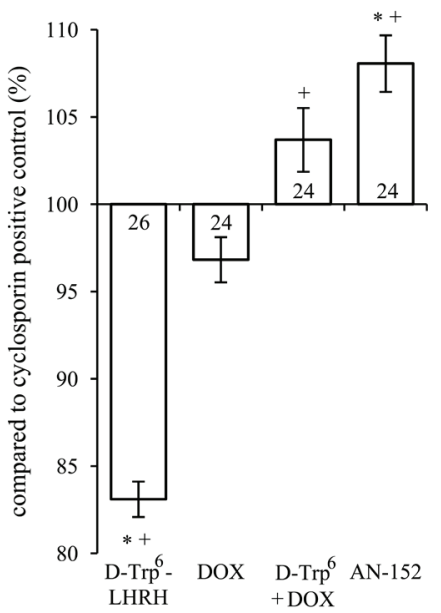

Figure 3: The effect of the treatment with AN-152 (AEZS-108) on the proliferation (A), apoptosis (B) and calcein retention (C) of U-87 MG cells. Sample numbers at the bottom of each column refer to the seeded wells, which underwent the given treatment. Abbreviations: DOX: doxorubicin, D-Trp ${ }^{6}+$ DOX: D-Trp - LHRH + doxorubicin. ${ }^{*}=\mathrm{p}<0.05$ vs. control $(\mathrm{n}=24) ;+=\mathrm{p}<0.05$ vs. DOX. 
Table 1: Relative expression of genes related to tumor growth

\begin{tabular}{|l|l|l|l|l|}
\hline Gene & $\begin{array}{l}\text { D-Trp6- } \\
\text { LHRH }\end{array}$ & DOX & $\begin{array}{l}\text { D-Trp6 } \\
\text { DOX }\end{array}$ & AN-152 \\
\hline Angiopoietin 1 & 0.71 & 0.51 & 0.65 & 0.2 \\
\hline Insulin-like growth factor 1 & 0.33 & 0.5 & 0.22 & 0.08 \\
\hline Integrin, $\alpha 4(\alpha 4$ subunit of VCAM-1 receptor) & 0.25 & 0.33 & 0.59 & $0.46^{*}$ \\
\hline Integrin, $\alpha \mathrm{V}$ (domain of vitronectin receptors) & $0.25^{*}$ & 0.38 & 0.57 & $0.32^{*}$ \\
\hline Integrin, $\beta 5$ (domain of vitronectin receptor) & 1.14 & 1.3 & 0.84 & $0.46^{*}$ \\
\hline Mitogen-activated protein kinase 1 & $0.65^{*}$ & 1 & 0.19 & 0.22 \\
\hline Melanoma cell adhesion molecule & $0.24^{*}$ & 0.57 & 0.19 & $0.06^{*}$ \\
\hline Matrix metalloproteinase 9 (gelatinase B) & 0.34 & 0.73 & 0.5 & $0.2^{*}$ \\
\hline Metastasis associated 1 family, member 2 & 0.6 & 1.02 & 1.2 & $0.68^{*}$ \\
\hline Nuclear factor $\kappa B$ & 0.85 & 1.13 & $0.11^{*}$ & $0.6^{*}$ \\
\hline Phosphoinositide-3-kinase, regulatory subunit $1 \alpha$ & $0.49^{*}$ & 0.74 & 0.67 & $0.67^{*}$ \\
\hline Plasminogen activator (urokinase) & 1.34 & $1.79^{*}$ & 0.8 & $0.6^{*}$ \\
\hline Platelet-derived growth factor $\alpha$ & 0.83 & 1.52 & 4.09 & $0.36^{*}$ \\
\hline Serpin, clade B, member 5 (maspin) & 0.16 & 0.14 & $17.67^{*}$ & 4.27 \\
\hline Tumor necrosis factor receptor superfamily, $10 \beta$ & 0.84 & 1.63 & 1.14 & $1.87^{*}$ \\
\hline V-raf-1 murine leukemia viral oncogene homolog 1 & 0.74 & 1.06 & 1.13 & $0.63^{*}$ \\
\hline
\end{tabular}

In vivo glioblastoma specimens were evaluated by Cancer Pathway RT2 Profiler PCR Array system. Only genes with at least three-fold or statistically significant changes are represented. Four tumor samples from each group were analyzed. Relative expressions are compared to the control. *p $<0.05$ vs. control. Abbreviations: DOX: doxorubicin, D-Trp6 + DOX: D-Trp6-LHRH + doxorubicin, VCAM: vascular cell adhesion molecule.

pathway (Table 1). This may lead to a direct inhibition of MDR-1 protein translocation/activation[29] and decreased resistance, which confirms our previous findings.[4, 30]

According to the signal transduction studies, AN152 influenced the cell-cycle, differentiation, contact and

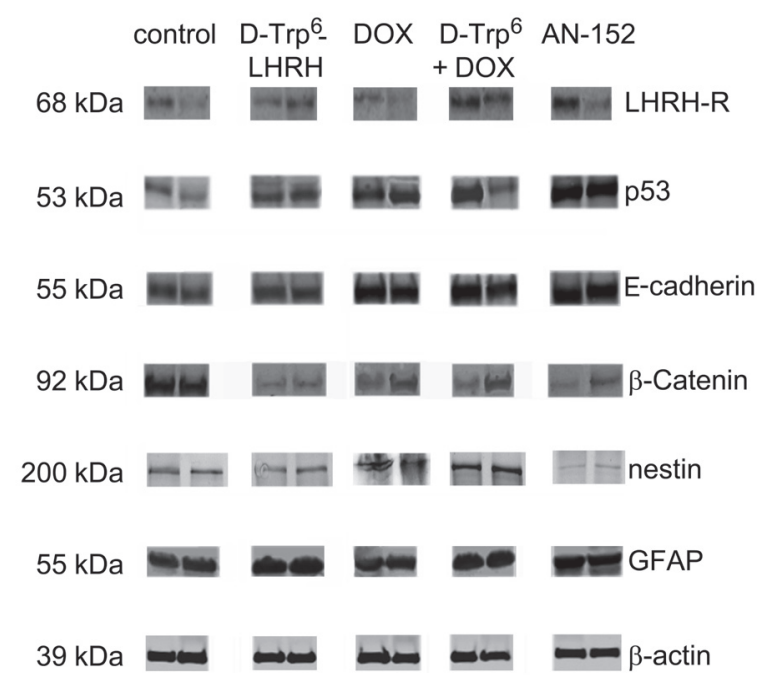

Figure 4: Western blot analyses of LHRH receptor and tumor marker expression following AN-152 treatment. Abbreviations: LHRH-R: luteinizing hormone releasing hormone receptor, GFAP: glial fibrillary acid protein, DOX: doxorubicin, D-Trp ${ }^{6}+$ DOX: D-Trp 6 -LHRH + doxorubicin. * = $\mathrm{p}<0.05$ vs. control. humoral control, angiogenesis and invasion. The cytotoxic analog increased levels of the pro-apoptotic tumor suppressor, p53, which molecule is frequently mutated in GBMs[31, 32] (Fig. 4-5). The increase of p53 can be related to the down-regulation of MTA2, which plays a role in the deacetylation and breakdown of p53.[33] The apoptosis stimulating potential of AN-152 is supported by the increased expression of the death domain containing TNF-R10 $\beta$ (Table 1).[34] The cytotoxic analog also suppressed the antiapoptotic NF- $\kappa \mathrm{B}$ expression.[35]

AN-152 mitigated the release of several glial growth factors, such as insulin-like growth factor I (IGF-I), FGF, and PDGF and also blocked the interwoven MAPK and PI3K-protein kinase B (PKB)/Akt survival pathways (Fig. 5, and Table 1).[36] The cytotoxic analog decreased the expression of MAPK-1, Raf-1 and the regulator subunit 1 (PIK3R1) of PI3K. Since growth promoting cytokines[37] are able to stimulate the survival cascades[38], both direct and indirect inhibition can explain the antiproliferative activity of AN-152.

The treatment with AN-152, according to the proteomic studies, also influenced the expression of the glial differentiation markers, nestin and GFAP (Fig. 4-5). $[39,40]$ During astrocyte maturation, nestin as a common neuroectodermal marker progressively disappears, while GFAP becomes the characteristic intermediary filament. In our experiments, DOX treatment elicited an increase in the expression of nestin and a decrease in the transcription 
of GFAP suggesting that, an undifferentiated, pluripotent clone became dominant upon treatment. Such cancer stem-like cell populations may retain the capability of expressing a wide array of resistance factors, which later would normally disappear, through differentiation.[41] Concersely, the cytotoxic analog elicited opposite changes, perhaps due to its "homing" neuropeptide molecule (Fig. 4-5).

AN-152 also exerted a beneficial effect on contact and humoral regulatory factors, which restrain tumor growth at a population level (Fig. 4-5, and Table). The increase in E-cadherin expression, and $\beta$-catenin degradation (Fig. 4-5) may inhibit the so-called cadherinswitch, when the expression pattern from E-cadherin changes to $\mathrm{N}$-cadherin, resulting in loss of adhesion and stimulation of invasion.[42, 43] Moreover, AN-152 decreased the transcription of three $(\alpha 4, \alpha \mathrm{V}, \beta 5)$ contact activator integrin domains (Table 1), which are frequently over-expressed in GBM tumors. [44]

Beside the pronounced inhibition of VEGF secretion (Fig. 5), the cytotoxic analog decreased the expression of angiopotein-1[45], and MCAM (Table 1), which are beneficial effects, since the suppression of angiogenesis is one of the most important complementary therapeutic approaches in the case of GBMs.[46] Beside neovascularisation, MCAM regulates cell proliferation through the PKB/Akt pathway, stimulates cell migration, increases the expression of MAPK and the proteolytic MMPs.[47] AN-152 also suppressed the expression of MMP-9 and the uPA and augmented the local tumor suppressor, maspin, level thus inhibiting the invasive capability activity of tumor cells (Table 1).[48, 49]

The present results, taken together with our previous findings promote the concept of a new, multi- faceted chemotherapeutic paradigm in the treatment of GBM, based on targeted peptide analogs. This concept is enhanced by the fact that analogs of hypothalamic peptide-hormones can cross the blood brain barrier.[50] Our results show that AN-152 is a versatile multi-pronged hybrid molecule which, beside direct antiproliferative and pro-apoptotic activity, elicits maturation. These features establish AN-152 as a very promising therapeutic option against brain cancers which express LHRH-R. In view of ongoing encouraging clinical phase I//II/III trials with AN152 (also denoted by its commercial designation, AEZS108 ) in gynecological, prostatic and urothelial cancers[1, $3,26,28]$, our findings strongly suggest a significant step forward in the successful therapy of malignant gliomas, curative treatment of which is not yet available.

\section{METHODS}

\section{Ethics Statement}

Investigation has been conducted in accordance with the ethical standards and according to the Declaration of Helsinki and according to national and international guidelines and has been approved by the authors' institutional review board.

\section{Peptides and chemicals}

The cytotoxic LHRH conjugate, AN-152, and the LHRH agonist D-Trp6-LHRH were synthesized in our laboratory as described[51]. DOX hydrochloride was

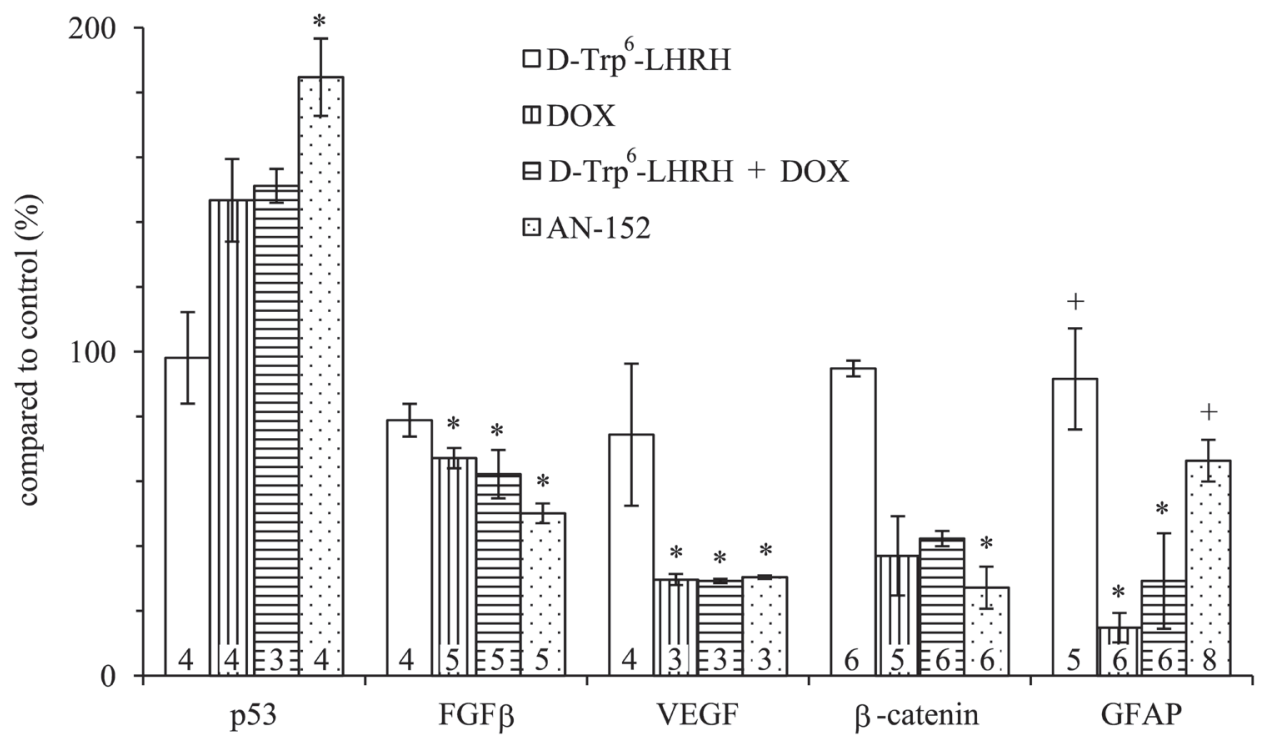

Figure 5: The effect of the treatment with AN-152 (AEZS-108) on the release of cytokines and signal transducers verified by ELISA experiments. Sample numbers at the bottom of each column refer to the seeded wells, which underwent the given treatment. Abbreviations: GFAP: glial fibrillary acid protein, DOX: doxorubicin. $*=p<0.05$ vs. control; $+=p<0.05$ vs. DOX 
obtained from Chemex Export-Import Gmbh (Vienna, Austria). The compounds were dissolved for injection in $5 \%(\mathrm{w} / \mathrm{v})$ aqueous D-mannitol solution as vehicle.

\section{Animal experiments}

Six-week-old female nude mice $(\mathrm{Ncr} n u / n u)$ were obtained from the NCI (Bethesda, MD). The animals were maintained according to the guidelines of the Institutional Animal Care and Use Committee, as described previously. $[52,53]$

\section{In vivo study design}

The animal studies with the U-87 MG GBM cell line (American Type Culture Collection, Manassas, VA) were performed as described previously [52]. Donor mice were injected in the flanks with $1 \times 106$ glioblastoma U-87 MG cells. After 4 weeks, tumor tissue grown in these donor animals was minced and passed through a wire mesh and a $150 \mu \mathrm{l}$ suspension of this was injected s.c. into experimental nude mice. The experiment was initiated when U-87 MG tumors had reached a volume of approximately $70 \mathrm{~mm} 3$. Mice bearing xenografts were randomized into 5 groups of 10 mice each with a random number generator function of Microsoft Excel (Microsoft Corp. Redmond, WA). The groups received, once weekly, the following intravenous treatment for 6 weeks, respectively: group 1: (control, 14 tumors, $100 \mu \mathrm{l}$ vehicle solution); group 2: (DOX, 14 tumors); group 3: (D-Trp6LHRH, 14 tumors); group 4: (DOX + D-Trp6-LHRH, 14 tumors); group 5: (AN-152, 15 tumors). The concentration of the compounds was equimolar $(413 \mathrm{nmol} / 20 \mathrm{~g})$ and was adjusted to the maximum tolerable dose of the cytotoxic drugs, which had proved the most effective in our previous oncological studies.[5-7, 52] Tumor dimensions were measured with microcalipers once a week and volume was calculated using the formula: (length $\times$ width $\times$ height $\times \pi) / 6$. Tumor doubling time was calculated using the formula: (study duration $\times$ LOG 2)/(LOG final tumor volume - LOG initial tumor volume).

\section{In vitro experiments}

\section{IHC}

Formalin-fixed, paraffin-embedded, surgically removed tissue samples were used for IHC. Three micron paraffin sections were stained by hematoxylin and eosin to confirm the presence of GBM. Adjacent serial sections were utilized for immunoperoxidase staining following standard protocols as previously described[54] and using a polyclonal antibody to LHRH-R (GnRHR-N20, Santa Cruz Biotechnology, Santa Cruz, CA). The sections were then counterstained with hematoxylin. Human pituitary glands (anterior lobe) obtained from autopsy were used as positive controls. The use of archival samples of GBM was approved by the institutional review board.

\section{Cell culturing}

U-87 MG cells were cultured in EMEM (ATCC) medium (supplemented with 10\% FBS, (ATCC) and $0.1 \%$ penicillin/streptomycin) at $37^{\circ} \mathrm{C}$ and $5 \% \mathrm{CO} 2$ atmosphere. This cell line is classified as grade IV GBM and was characterized and deposited by J. Ponten and associates.[55] As a treatment, those doses $(100 \mathrm{nM})$ of AN-152 were used which had proved most effective in our previous studies[56]. Other compounds were administered in equimolar concentrations.

\section{Proliferation and apoptosis assays in vitro}

For proliferation studies, 104 cells/well were seeded in $100 \mu \mathrm{l}$ medium, in a 96-well plate and were then incubated for $24 \mathrm{~h}$ in a humidified incubator at 37 ${ }^{\circ} \mathrm{C}$. Next, culture medium was replaced with FBS free medium (starvation) for $24 \mathrm{~h}$. After another $24 \mathrm{~h}$, the cells were exposed to complete medium containing $100 \mathrm{nM}$ of AN-152, DOX, D-Trp6-LHRH, or the combination of DOX and D-Trp6-LHRH. The cells were then incubated for $48 \mathrm{~h}$. The effect of the compounds on cell proliferation was evaluated by using the 3-(4,5-Dimethylthiazol-2-yl)2,5-diphenyltetrazolium bromide (MTT) assay (CellTiter 96® Non-Radioactive Cell Proliferation Assay, Promega, Madison, WI, USA), according to the manufacturer's instructions with the help of a Victor3 multilabel counter (Perkin-Elmer, Waltham, MD, USA)(5). Determination of apoptosis was performed on freshly seeded cell samples (104 cells/well, in $100 \mu \mathrm{l}$ media, in a 96-well plate) by the Multi-Parameter Apoptosis Assay Kit (Cayman Chemical Company, Ann Arbor, MI), according to the manufacturer's instruction.

\section{Multidrug resistance assay}

This assay was performed according to the manufacturer's instructions (Cayman Chemical Company, Ann Arbor, MI). U-87 MG cells were seeded in $5 \times 104$ cells/well density in $100 \mu \mathrm{l}$ medium, to 96-well, black, clear bottom plates and were grown overnight in a humidified incubator at $37^{\circ} \mathrm{C}$. The next day the medium was discarded, and the cells were treated with medium containing $100 \mathrm{nM}$ of AN-152, DOX, D-Trp6-LHRH, or the combination of DOX and D-Trp6-LHRH. As a positive control Cyclosporin-A solution was used in 1/1000 dilution according to the manufacturer's description. Afterwards, the cells were incubated for $1 \mathrm{~h}$, then calcein AM/Hoechst dye combined staining solution was added. Fifteen 
minutes later both cell density (at excitation and emission wavelengths of $355 \mathrm{~nm}$ and $465 \mathrm{~nm}$, respectively) and calcein retention (at excitation and emission wavelengths of $485 \mathrm{~nm}$ and $535 \mathrm{~nm}$, respectively) were detected with the help of a Victor3 multilabel counter (Perkin-Elmer, Waltham, MD, USA). Relative calcein retention values were expressed as a function of cell density.

\section{Total RNA isolation and reverse transcription}

Total RNA was isolated from representative, DNAse treated, U-87 MG tumor samples using a NucleoSpin kit according to the manufacturer's instructions (MachereyNagel Inc., Bethlehem, PA). Four tumor samples from each group were analyzed. The yield and the quality of RNA samples were determined spectrophotometrically using $260 \mathrm{~nm}$, and 260/280 and 260/230 nm ratios. The synthesis of cDNA was performed as described[57]. Briefly, $1 \mu \mathrm{g}$ of RNA from each sample was reversetranscribed into cDNA by RT First Strand kit (Qiagen). Reverse transcription was done in a Veriti 96-well thermal cycler (Applied Biosystems).

\section{Cancer Pathway Finder quantitative PCR array}

The Human Cancer Pathway Finder quantitative PCR array (PAHS-033A, Qiagen) used in our study contains 84 unique genes related to cell proliferation, apoptosis, cell cycle, angiogenesis, invasion and metastasis. All PCR arrays were studied using iQ5 Multicolor Real-Time Detections System (Bio-Rad). All genes represented by the array showed a single peak on the melting curve characteristic of the specific products. Four tumor samples from each group were analyzed. Data analysis of gene expression was performed using Excel based PCR Array Data Analysis Software provided by the manufacturer (Qiagen): fold-changes in gene expression were calculated using the $\Delta \Delta \mathrm{Ct}$ method and five stably expressed housekeeping genes (B2M, HPRT1, RPL13A, GAPDH, and ACTB) were used for normalization of the results.

\section{Western blot analyses}

Proteins from the tumor tissue were isolated using the Macherey-Nagel NucleoSpin kit. The protein concentrations of the supernatant were determined by NanoDrop (NanoDrop Technologies Inc., Wilmington, DE). Equal amounts of protein were resuspended in sample loading buffer $(0.25 \mathrm{M}$ Trizma Base, $8 \%$ SDS, 40\% glycerol, $0.004 \%$ bromophenol blue, 4\% b-mercaptoethanol; $\mathrm{pH}$ 6.8), boiled for 3 min and separated by $12 \%$ SDS-polyacrylamide gel electrophoresis. Proteins from the gel were transferred onto nitrocellulose membranes, which were blocked with $50-50 \%$ Tris-buffered saline (TBS) $(20 \mathrm{mM}$ Tris- $\mathrm{HCl}$ $\mathrm{pH}: 7.5,150 \mathrm{mM} \mathrm{NaCl}$ ): Odyssey blocking buffer for $1 \mathrm{~h}$ at room temperature, followed by an overnight incubation at $4^{\circ} \mathrm{C}$ with the following primary antibodies: nestin (cat. no.: ab92391), glial fibrillary acid protein (GFAP) (cat. no.: ab48050, both from AbCam Inc., Cambridge, MA), LHRH-R (sc-13944), $\beta$-actin (cat. no.: sc-47778, both from Santa Cruz Biotechnology, Inc., Santa Cruz, CA), $\beta$-catenin (cat. no.: 9562), E-cadherin, (cat. no.: 3195), p21 (cat. no.: 2947), p53 (cat. no.: 9282, all from Cell Signaling Technology Inc. (Danvers, MA). The signals were developed by incubating the membrane for $1 \mathrm{~h}$ at room temperature with the appropriate Infrared IRDye $\square$-labeled secondary antibodies (1:10000; LICOR Biosciences, Lincoln, NE) and were then visualized with the Odyssey Infrared Imaging System (LI-COR Biosciences, Lincoln, NE). The protein bands were quantified using V3.0 software (LI-COR Biosciences, Lincoln, NE) and integrated densitiy values (IDV)s of duplicate experiments were calculated.

\section{ELISA assays for the determination of oncoprotein and tumor suppressor expression.}

U-87 MG cells (105 cells per well) were seeded onto 6-well plates, cultured overnight, and then exposed to the previously outlined treatments $(100 \mathrm{nM}$ of DOX, D-Trp6-LHRH, AN-152 or the combination of DOX and D-Trp6-LHRH) for 24 hours. Concentrations of specific proteins in cell lysates were determined according to the manufacturer's instructions. Human p53 and vascular endothelial growth factor (VEGF) ELISA kits were purchased from Biovendor, LLC (Candler, NC), fibroblast growth factor (FGF) basic human ELISA kit was obtained from AbCam Inc., total $\beta$-Catenin ELISA kits were received from Cell Signaling Technology, and GFAP human ELISA kit was purchased from Cayman Chemical Company. One or two plates were run and readings were normalized to protein concentrations determined by NanoDrop (NanoDrop Technologies Inc., Wilmington, DE).

\section{Statistical analyses}

Statistical analyses were performed using either t-test for independent samples (two-sided, for PCR assays), univariate analysis of variance (ANOVA) (in vitro studies) or repeated measure ANOVA (in vivo experiment). ANOVA was followed by Tukey's post hoc tests for group-wise comparisons. Results are expressed either as the means \pm SEM (in vitro studies) or as means and pooled standard errors (in vivo studies). Differences with $\mathrm{p}<0.05$, compared to the control, were considered statistically significant. Data reductions and statistical 
analyses were performed by SigmaPlot 12.0 (Systat Software, Inc., Chicago, IL) and IBM SPSS Statistics 20.0 (IBM Corporation, Armonk, NY).

\section{ACKNOWLEDGEMENTS}

The work described in this paper was supported by the Medical Research Service of the Veterans Affairs Department, University of Miami, Miller School of Medicine, Departments of Pathology and Medicine, Division of Hematology/Oncology, the South Florida Veterans Affairs Foundation for Research and Education (both to A.V.S.) and the L. Austin Weeks Endowment for Urologic Research (to N.L.B.). This work was also supported in part by a grant from the Urology Care Foundation Research Scholars Program and the AUA Southeastern Section (to F.G.R.). M.J. is on leave from the Department of Pathophysiology, University of Szeged, Hungary.

\section{Conflicts of Interest and Source of Funding:}

Dr A.V. Schally is listed as co-inventor on the Tulane University patent on AN-152 (AEZS-108). Dr. Schally receives a grant for research on $\mathrm{AN}-152$ from Aeterna/Zentaris.

\section{REFERENCES}

1. Schally AV, Engel JB, Emons G, Block NL and Pinski J. Use of analogs of peptide hormones conjugated to cytotoxic radicals for chemotherapy targeted to receptors on tumors. Curr Drug Deliv. 2011; 8(1):11-25.

2. Schally AV and Halmos G. (2012). Targeting to Peptide Receptors. In: Kratz F, Senter P and Steinhagen H, eds. Drug Delivery in Oncology. (Weinheim: Wiley-VCH), pp. 1219-1261.

3. Engel J, Emons G, Pinski J and Schally AV. AEZS-108 : a targeted cytotoxic analog of LHRH for the treatment of cancers positive for LHRH receptors. Expert Opin Investig Drugs. 2012; 21(6):891-899.

4. Gunthert AR, Grundker C, Bongertz T, Schlott T, Nagy A, Schally AV and Emons G. Internalization of cytotoxic analog AN-152 of luteinizing hormone-releasing hormone induces apoptosis in human endometrial and ovarian cancer cell lines independent of multidrug resistance-1 (MDR-1) system. Am J Obstet Gynecol. 2004; 191(4):1164-1172.

5. Seitz S, Schally AV, Treszl A, Papadia A, Rick F, Szalontay L, Szepeshazi K, Ortmann O, Halmos G, Hohla F and Buchholz S. Preclinical evaluation of properties of a new targeted cytotoxic somatostatin analog, AN-162 (AEZS$124)$, and its effects on tumor growth inhibition. Anticancer Drugs. 2009; 20(7):553-558.

6. Hohla F, Buchholz S, Schally AV, Krishan A, Rick FG,
Szalontay L, Papadia A, Halmos G, Koster F, Aigner E, Datz $\mathrm{C}$ and Seitz S. Targeted cytotoxic somatostatin analog AN-162 inhibits growth of human colon carcinomas and increases sensitivity of doxorubicin resistant murine leukemia cells. Cancer Lett. 2010; 294(1):35-42.

7. Treszl A, Schally AV, Seitz S, Szalontay L, Rick FG, Szepeshazi K and Halmos G. Inhibition of human non-small cell lung cancers with a targeted cytotoxic somatostatin analog, AN-162. Peptides. 2009; 30(9):1643-1650.

8. Seitz S, Buchholz S, Schally AV, Jayakumar AR, Weber F, Papadia A, Rick FG, Szalontay L, Treszl A, Koster F, Ortmann $\mathrm{O}$ and Hohla F. Targeting triple-negative breast cancer through the somatostatin receptor with the new cytotoxic somatostatin analogue AN-162 [AEZS-124]. Anticancer Drugs. 2013; 24(2):150-157.

9. Schally AV, Arimura A, Kastin AJ, Matsuo H, Baba Y, Redding TW, Nair RM, Debeljuk L and White WF. Gonadotropin-releasing hormone: one polypeptide regulates secretion of luteinizing and follicle-stimulating hormones. Science. 1971; 173(4001):1036-1038.

10. Hsueh AJ and Schaeffer JM. Gonadotropin-releasing hormone as a paracrine hormone and neurotransmitter in extra-pituitary sites. J Steroid Biochem. 1985; 23(5B):757764.

11. Rick FG, Schally AV, Block NL, Halmos G, Perez R, Fernandez JB, Vidaurre I and Szalontay L. LHRH antagonist Cetrorelix reduces prostate size and gene expression of proinflammatory cytokines and growth factors in a rat model of benign prostatic hyperplasia. Prostate. 2011; 71(7):736-747.

12. Rick FG, Szalontay L, Schally AV, Block NL, Nadji M, Szepeshazi K, Vidaurre I, Zarandi M, Kovacs M and Rekasi Z. Combining growth hormone-releasing hormone antagonist with luteinizing hormone-releasing hormone antagonist greatly augments benign prostatic hyperplasia shrinkage. J Urol. 2012; 187(4):1498-1504.

13. Rick FG, Schally AV, Block NL, Abi-Chaker A, Krishan A and Szalontay L. Mechanisms of synergism between antagonists of growth hormone-releasing hormone and antagonists of luteinizing hormone-releasing hormone in shrinking experimental benign prostatic hyperplasia. Prostate. 2013.

14. Harrison GS, Wierman ME, Nett TM and Glode LM. Gonadotropin-releasing hormone and its receptor in normal and malignant cells. Endocr Relat Cancer. 2004; 11(4):725748.

15. Ebling FJ and Cronin AS. The neurobiology of reproductive development. Neuroreport. 2000; 11(16):R23-33.

16. Yamamoto $\mathrm{N}$. Three gonadotropin-releasing hormone neuronal groups with special reference to teleosts. Anat Sci Int. 2003; 78(3):139-155.

17. Zhou JN and Swaab DF. Activation and degeneration during aging: a morphometric study of the human hypothalamus. Microsc Res Tech. 1999; 44(1):36-48. 
18. Cariboni A and Maggi R. Kallmann's syndrome, a neuronal migration defect. Cell Mol Life Sci. 2006; 63(21):25122526.

19. Sanai N, Alvarez-Buylla A and Berger MS. Neural stem cells and the origin of gliomas. N Engl J Med. 2005; 353(8):811-822.

20. Wen PY and Kesari S. Malignant gliomas in adults. N Engl J Med. 2008; 359(5):492-507.

21. Marelli MM, Moretti RM, Mai S, Muller O, Van Groeninghen JC and Limonta P. Novel insights into GnRH receptor activity: role in the control of human glioblastoma cell proliferation. Oncol Rep. 2009; 21(5):1277-1282.

22. van Groeninghen JC, Kiesel L, Winkler D and Zwirner M. Effects of luteinising-hormone-releasing hormone on nervous-system tumours. Lancet. 1998; 352(9125):372-373.

23. Albertsen P. Androgen deprivation in prostate cancer--step by step. N Engl J Med. 2009; 360(24):2572-2574.

24. Reissmann T, Schally AV, Bouchard P, Riethmiiller H and Engel J. The LHRH antagonist cetrorelix: a review. Hum Reprod Update. 2000; 6(4):322-331.

25. Emons G, Sindermann H, Engel J, Schally AV and Grundker C. Luteinizing hormone-releasing hormone receptor-targeted chemotherapy using AN-152. Neuroendocrinology. 2009; 90(1):15-18.

26. Engel JB and Schally AV. Drug Insight: clinical use of agonists and antagonists of luteinizing-hormone-releasing hormone. Nat Clin Pract Endocrinol Metab. 2007; 3(2):157167.

27. Kidd M, Schally AV, Pfragner R, Malfertheiner MV and Modlin IM. Inhibition of proliferation of small intestinal and bronchopulmonary neuroendocrine cell lines by using peptide analogs targeting receptors. Cancer. 2008; 112(6):1404-1414.

28. Szepeshazi K, Schally AV, Keller G, Block NL, Benten D, Halmos G, Szalontay L, Vidaurre I, Jaszberenyi M and Rick FG. Receptor-targeted therapy of human experimental urinary bladder cancers with cytotoxic LH-RH analog AN152 [AEZS- 108]. Oncotarget. 2012; 3(7):686-699.

29. Shen H, Xu W, Luo W, Zhou L, Yong W, Chen F, Wu C, Chen Q and Han X. Upregulation of mdr1 gene is related to activation of the MAPK/ERK signal transduction pathway and YB-1 nuclear translocation in B-cell lymphoma. Exp Hematol. 2011; 39(5):558-569.

30. Keller G, Schally AV, Nagy A, Baker B, Halmos $G$ and Engel JB. Effective therapy of experimental human malignant melanomas with a targeted cytotoxic somatostatin analogue without induction of multi-drug resistance proteins. Int J Oncol. 2006; 28(6):1507-1513.

31. Cox LS. Multiple pathways control cell growth and transformation: overlapping and independent activities of p53 and p21Cip1/WAF1/Sdi1. J Pathol. 1997; 183(2):134140.

32. Stegh AH and DePinho RA. Beyond effector caspase inhibition: Bc12L12 neutralizes p53 signaling in glioblastoma. Cell Cycle. 2011; 10(1):33-38.

33. Luo J, Su F, Chen D, Shiloh A and Gu W. Deacetylation of p53 modulates its effect on cell growth and apoptosis. Nature. 2000; 408(6810):377-381.

34. Hendruschk S, Wiedemuth R, Aigner A, Topfer K, Cartellieri M, Martin D, Kirsch M, Ikonomidou C, Schackert $\mathrm{G}$ and Temme A. RNA interference targeting survivin exerts antitumoral effects in vitro and in established glioma xenografts in vivo. Neuro Oncol. 2011; 13(10):1074-1089.

35. Karin M. Nuclear factor-kappaB in cancer development and progression. Nature. 2006; 441(7092):431-436.

36. Igney FH and Krammer PH. Death and anti-death: tumour resistance to apoptosis. Nat Rev Cancer. 2002; 2(4):277288.

37. Jeuken J, van den Broecke C, Gijsen S, Boots-Sprenger S and Wesseling P. RAS/RAF pathway activation in gliomas: the result of copy number gains rather than activating mutations. Acta Neuropathol. 2007; 114(2):121-133.

38. Rosenwald IB. The role of translation in neoplastic transformation from a pathologist's point of view. Oncogene. 2004; 23(18):3230-3247.

39. Strojnik T, Kavalar R and Lah TT. Experimental model and immunohistochemical analyses of U87 human glioblastoma cell xenografts in immunosuppressed rat brains. Anticancer Res. 2006; 26(4B):2887-2900.

40. Ho CL and Liem RK. Intermediate filaments in the nervous system: implications in cancer. Cancer Metastasis Rev. 1996; 15(4):483-497.

41. Ying M, Wang S, Sang Y, Sun P, Lal B, Goodwin CR, Guerrero-Cazares H, Quinones-Hinojosa A, Laterra J and Xia S. Regulation of glioblastoma stem cells by retinoic acid: role for Notch pathway inhibition. Oncogene. 2011; 30(31):3454-3467.

42. Huber MA, Kraut N and Beug H. Molecular requirements for epithelial-mesenchymal transition during tumor progression. Curr Opin Cell Biol. 2005; 17(5):548-558.

43. Cavallaro $\mathrm{U}$ and Christofori $\mathrm{G}$. Cell adhesion and signalling by cadherins and Ig-CAMs in cancer. Nat Rev Cancer. 2004; 4(2):118-132.

44. Tabatabai G, Weller M, Nabors B, Picard M, Reardon D, Mikkelsen T, Ruegg C and Stupp R. Targeting integrins in malignant glioma. Target Oncol. 2010; 5(3):175-181.

45. Stratmann A, Risau W and Plate KH. Cell type-specific expression of angiopoietin-1 and angiopoietin-2 suggests a role in glioblastoma angiogenesis. Am J Pathol. 1998; 153(5):1459-1466.

46. Norden AD, Drappatz J and Wen PY. Antiangiogenic therapies for high-grade glioma. Nat Rev Neurol. 2009; 5(11):610-620.

47. Ouhtit A, Gaur RL, Abd Elmageed ZY, Fernando A, Thouta R, Trappey AK, Abdraboh ME, El-Sayyad HI, Rao P and Raj MG. Towards understanding the mode of action of the multifaceted cell adhesion receptor CD146. Biochim 
Biophys Acta. 2009; 1795(2):130-136.

48. Eitel JA, Bijangi-Vishehsaraei K, Saadatzadeh MR, Bhavsar JR, Murphy MP, Pollok KE and Mayo LD. PTEN and p53 are required for hypoxia induced expression of maspin in glioblastoma cells. Cell Cycle. 2009; 8(6):896-901.

49. Zhao Y, Lyons CE, Jr., Xiao A, Templeton DJ, Sang QA, Brew $\mathrm{K}$ and Hussaini IM. Urokinase directly activates matrix metalloproteinases-9: a potential role in glioblastoma invasion. Biochem Biophys Res Commun. 2008; 369(4):1215-1220.

50. Jaeger LB, Banks WA, Varga JL and Schally AV. Antagonists of growth hormone-releasing hormone cross the blood-brain barrier: a potential applicability to treatment of brain tumors. Proc Natl Acad Sci U S A. 2005; 102(35):12495-12500.

51. Nagy A, Schally AV, Armatis P, Szepeshazi K, Halmos G, Kovacs M, Zarandi M, Groot K, Miyazaki M, Jungwirth A and Horvath J. Cytotoxic analogs of luteinizing hormone-releasing hormone containing doxorubicin or 2-pyrrolinodoxorubicin, a derivative 500-1000 times more potent. Proc Natl Acad Sci U S A. 1996; 93(14):7269-7273.

52. Pozsgai E, Schally AV, Halmos G, Rick F and Bellyei S. The inhibitory effect of a novel cytotoxic somatostatin analogue AN-162 on experimental glioblastoma. Horm Metab Res. 2010; 42(11):781-786.

53. Jaszberenyi M, Schally AV, Block NL, Zarandi M, Cai RZ, Vidaurre I, Szalontay L, Jayakumar AR and Rick FG. Suppression of the proliferation of human U-87 MG glioblastoma cells by new antagonists of growth hormonereleasing hormone in vivo and in vitro. Targeted oncology. 2013.

54. Rozsa B, Nadji M, Schally AV, Dezso B, Flasko T, Toth G, Mile M, Block NL and Halmos G. Receptors for luteinizing hormone-releasing hormone (LHRH) in benign prostatic hyperplasia (BPH) as potential molecular targets for therapy with LHRH antagonist cetrorelix. Prostate. 2011; 71(5):445-452.

55. Ponten $\mathrm{J}$ and Macintyre EH. Long term culture of normal and neoplastic human glia. Acta Pathol Microbiol Scand. 1968; 74(4):465-486.

56. Gunthert AR, Grundker C, Bongertz T, Nagy A, Schally $\mathrm{AV}$ and Emons G. Induction of apoptosis by AN-152, a cytotoxic analog of luteinizing hormone-releasing hormone (LHRH), in LHRH-R positive human breast cancer cells is independent of multidrug resistance-1 (MDR-1) system. Breast Cancer Res Treat. 2004; 87(3):255-264.

57. Rick FG, Schally AV, Szalontay L, Block NL, Szepeshazi K, Nadji M, Zarandi M, Hohla F, Buchholz S and Seitz S. Antagonists of growth hormone-releasing hormone inhibit growth of androgen-independent prostate cancer through inactivation of ERK and Akt kinases. Proc Natl Acad Sci U S A. 2012; 109(5):1655-1660. 